generally agreed that in future one copy of every dissertation with a strong bearing on a single African country could be supplied to the library functioning as National Library in that country. This would provide for those dissertations of which sufficient copies have been received by the donating library, i.e. about 60 per cent of all Western German dissertations concerned. A list of the receiving libraries will be established with the help of the embassies of the various African countries in Germany. It is hoped that this development will strengthen the international co-operation between libraries and the cultural links between their countries.

(Communicated by Dr. H.-J. Scholz)

\title{
Some Recent Bibliographies
}

Bibliographie générale de la Haute-Volta, 1956-65, by Françoise Izard, assisted by P. H. Bonnefond and M. d'Huart. Paris: C.N.R.S.; Ouagadougou : C.V.R.S., r967 (Recherches voltaïques, 7): I,54I entries arranged by subject, with author, subject, ethnic and linguistic, and periodical indexes.

Catalogue des publications et rapports duservice dessciences humaines (1949-67), by André Jacquot. Brazzaville: Office de la recherche scientifique et technique outre-mer (O.R.S.T.O.M.), 1968; ninety-one pages listing published and unpublished books, articles, and reports, etc. by twenty-five researchers and technicians associated with the Centre O.R.S.T.O.M. at Brazzaville : arranged alphabetically by authors, subjects, and regions.

Pygmées et autres races de petite taille (Boschimans, Hottentots, Negritos, etc.): bibliographie générale, by Max Liniger-Goumaz. Genève : Éditions du Temps, 1968 ; 335 pages containing 3,282 entries, with indexes of periodicals, authors, peoples, and regions.

A Preliminary List of Publications Referring to the Non-Bantu Click Languages, compiled by Leah Levy. Department of African Languages, School of African Studies, University of Cape Town, 1968. The bibliography is in two parts, of which this is the first. It presents the author index with detailed references wherever these could be obtained. The second patr, which is in preparation, will be the language index containing an analysis of the works presented on each language; it will also show what part of the total language structure from phoneme to literature has been covered and what still needs to be known.

The Luo of Kenya: an Annotated Bibliography, by Carole E. DuPré. Washington D.C.: Institute for Cross-Cultural Research, 1968. \$2.95 (cloth), \$1.95 (paper); 130 annotated entries, with essays on Luo life as revealed in the literature, and an analysis of the literature itself; author index.

\section{'The Matrilineal Peoples of Eastern Tanzania': Bibliographical Corrigenda and Addenda}

Professor T. O. Beidelman writes: 'In my contribution to this section of the Ethnographic Survey of Africa (East Central Africa, Part XVI) there are a number of errors and important omissions. As these bibliographies are a major value of the series $I$ wish to correct these errors and make some additions for the benefit of future researchers.'

\section{Errata}

Beidelman, T. O. 1966, read 1967. Kaguru Folklore and the Concept of Reciprocity. Zeitschrift für Ethnologie, xcii. 74-88.

- 1966d, read 1967. Intertribal Tensions in Some Local Government Courts in Colonial Tanganyika (Part 2). Journal of African Law, xi. 27-45.

— 1966e, read 1967. The Hehe of Ukaguru. Afrika und Übersee, 1. 304-14. 
- 1967c, read Eleven Kaguru Tales. African Studies, xxvi. 3-36.

- 1967d, read 1968. Eight Kaguru Tales: a Contribution toward a Survey of Kaguru Folklore and Cosmology. Anthropos, lxii. 69-93.

Horner, R. P., read Gaume (ed.). Voyage à la côte orientale de l'A frique pendant l'année I 866 par le R. P. Horner, Gaume, Paris.

Paulssen, F. 1882, read 1922.

Schneider, G. 1788, read 1877 .

Velten, C. (ed.) r 901 . Safari za Wasuaheli; Schilderungen der Suaheli. Both a Swahili and German edition exist, with the same publisher and date of publication: Vandenhoeck und Rupprecht, Göttingen. This contains the following essays relevant to the area (pagination from the German edition):

Mwenyi Hamisi esh-Shirazi, Meine Reise ins Innere Ostafrikas bis zum Tanganyika, pp. I-5s.

Selim bin Abakari, Meine Reise nach dem Nyassen mit der Dampferexpedition des Herrn Major von Wissmann, pp. 56-115; Meine Reise nach Europa von Daressalam bis Berlin, pp. I $16-37$.

Mtoro bin Mwenyi Bakari, Meine Reise nach Udoe bis Uzigua sowie Geschichtliches über die Wadoe und Sitten und Gebräuchen der Wazaramu zusammengestellt, pp. 22 s76.

Abdallah bin Rashid, Meine Reise durch Afrika vom Indischen bis zum Atlantischen Ozean als Teilnehmer der Expedition des Herrn Graf von Goetzen, pp. 198-224.

(All of the above contain useful comments on Zaramo, Zigula, Kwere, etc.)

Winter, E. H., and Beidelman, T. O., n.d. read I968. Tanganyika, pp. 57-204, in Contemporary Changes in Traditional Societies (ed. J. H. Steward), vol. i, University of Illinois Press, Urbana.

\section{Addenda}

Bauer, R. P. 1882. Voyage dans l'Oudoé et l'Ouzigoua (Zanguebar), Lyon. (Not available.)

Bauer, R. P., and LeRoy, R. P. 1886. A travexs le Zanguebar: voyage dans l'Oudoé, l'Ouzigoua, l'Oukwere et l'Ousagara (I880-82), Mame, Tours. (Not available; probably another version of the preceding item.)

Beidelman, T. O. 1968. A Case of Kaguru Oral History. Baessler-Archiv, 16, pp. 357-71.

- 1969. Myth, Legend and Oral History: a Kaguru Traditional Text. Anthropos: forthcoming.

Bennett, N. 1963. The Holy Ghost Mission in East Africa 1858-1890, pp. 54-75, in Studies in East African History (ed. N. Bennett), Boston University Press, Boston. (A useful survey, bibliographic sources.)

Courmant, Mgr de. I889. Lettre de Mgr de Courmant. Annales de la Propagation de la Foi, lxi. 47-63. (Very useful comments on all of the early Roman Catholic mission stations; a few comments on Ungulu (Mhonda, Mandera); on missions in Uzaramo (Bagamoyo); Uluguru (Morogoro); Usagara (Kondoa, Ilonga); Ukami (Tununguo).)

Gaume (ed.) I 872 . Voyage à la côte orientale de l'A Arique pendant l'année 1866 par le R. P. Horner. Gaume, Paris. (Unseen; French version of next item in bibliography.)

1873. Reisen in Zanguebar in den Jahren 1867 und 1879 von Pater Horner herausgegeben von Dr. Gaume. Manz, Regensberg. (Not available; most likely a German version of the French edition also edited by Gaume.)

Karst, R. P. 1912. Lettre du R. P. Karst. Annales de la Propagation de la Foi, lxxxvi. 47-63. (Very useful comments on early conditions in Morogoro mission and town; on Luguru-Arab-German relations.)

Kenyon, E. R. 1909. Missions in Eastern Equatorial Africa. The East and the West: Quarterly 